\title{
Comparative pharmacokinetic and renal clearance study of ceftiofur in cross breed Friesian and Buffalo calves
}

\author{
A. A. M. El-Gendy ${ }^{1 *}$, M. A. Tohamy ${ }^{1}$, M. Ismail ${ }^{2}$ \\ ${ }^{1}$ Pharmacology Department, Faculty of Veterinary Medicine, Beni-Suef University, Beni-Suef,Egypt \\ ${ }^{2}$ Pharmacology Department, Faculty of Veterinary Medicine, Cairo University, Giza, Egypt
}

\begin{abstract}
The pharmacokinetic profile of ceftiofur sodium, a third generation cephalosporin, was studied in both Friesian and buffalo calves following a single intravenous and intramuscular administration of $2.2 \mathrm{mg} \mathrm{kg}^{-1}$ b.wt. in a cross over study with 15-day wash out period. After i.v administration the serum concentration-time curve of ceftiofur sodium was best fitted using two-compartments open model, with distribution half-lives $\left(t_{1 / 2(\alpha)}\right)$ of 0.384 and 0.176 h., elimination half-lives $\left(t_{1 / 2(\beta)}\right)$ of 5.047 and 1.607 h., mean residence time (MRT) of 6.926 and $2.072 \mathrm{~h}$., volumes of distribution at steady-state $\left(\mathrm{Vd}_{\mathrm{ss}}\right)$ of 0.206 and $0.134 \mathrm{~L} \mathrm{~kg}^{-1}$ and total body clearance $\left(\mathrm{Cl}_{\mathrm{B}}\right)$ of 0.029 and $0.065 \mathrm{~L} \mathrm{~kg}^{-1} \mathrm{~h}^{-1}$ in Friesian and buffalo calves, respectively. Following intramuscular administration, the drug absorbed with half-lives of absorption $\left(t_{1 / 2(a b)}\right)$ of 1.010 and $0.217 \mathrm{~h}$., maximum serum concentrations $\left(C_{\max }\right)$ of 5.539 and $9.663 \mathrm{\mu g} \mathrm{ml}^{-1}$ which attained after $\left(t_{\max }\right)$ of 3.147 and $0.825 \mathrm{~h}$. and the drug was eliminated with half-lives $\left(t_{1 /(e l)}\right)$ of 5.239 and $1.750 \mathrm{~h}$. in Friesian and buffalo calves, respectively. The systemic intramuscular bioavailabilities were 89.82 and $99.7 \%$, while the in-vitro serum proteinbinding tendencies were 39.68 and $14.44 \%$ in Friesian and buffalo calves, respectively.
\end{abstract}

Ceftiofur sodium is a third-generation cephalosporin which is approved for use in cattle, pigs, poultry, horses and dogs in united states (Crosier et al., 1996). It has a broadspectrum activity against Gram-positive and Gram-negative aerobic and some anaerobic bacteria. Owing to the antibiotic's high efficacy against Pasteurella haemolytica, Pasteurella multocida and Haemophilus somnus (Anonymous, 1991; Jaglan et al., 1992) ceftiofur sodium is approved in many countries worldwide for the treatment of bovine respiratory disease affecting beef and lactating dairy cattle (Clarke et al., 1996). In beef cattle, ceftiofur sodium is used primarily to treat shipping fever, an acute bronchopneumonia that often occurs following transport to feed lots (Sweeney and Smith, 1990). In dairy cattle, ceftiofur sodium is indicated for the treatment of enzootic calf pneumonia (Sweeney and Smith, 1990; Anonymous, 1991).

The pharmacokinetics of ceftiofur in various

* Corresponding author. Tel.: +20 105380875; fax: +20822327982 .

E-mail address: elgendyab@yahoo.com

(A.A.M. El-Gendy). species was reviewed by Brown et al. (1991). Since that time, additional reports have appeared for cattle (Soback et al., 1991; Halstead et al., 1992; Erskine et al., 1995; Whittem et al., 1995; Brown et al., 1996), horses (Meyer et al., 1992; Jaglan et al., 1994), dogs (Brown et al., 1995), sheep (Craigmill et al., 1997) and dairy goats (Courtin et al., 1997). A preliminary report on the pharmacokinetics of ceftiofur in sheep (Craigmill et al., 1991) showed that the pharmacokinetics in sheep were very similar to those seen in cattle. Another preliminary report (Courtin et al., 1994) showed the pharmacokinetic parameters in goats to be similar to sheep.

However, there is no published information about the pharmacokinetics of ceftiofur sodium in buffalo calves. The purpose of this study was to determine the pharmacokinetic, bioavailability and renal clearance of ceftiofur sodium in buffalo calves compared to Friesian calves after a single intravenous and intramuscular injection in order to establish adequate dose regimen for potential clinical use in infection of calves with susceptible microorganisms. 
Materials and Methods

Antimicrobial agent. Ceftiofur sodium (Excenel ${ }^{\mathrm{TM}}$, sterile powder, Upjhon Limited, Animal Health Crawley, RH10 2LZ, U.K.) was used. Each vial contains ceftiofur sodium, equivalent to $4 \mathrm{gm}$ ceftiofur. Each $\mathrm{ml}$ of reconstituted solution contains ceftiofur sodium equivalent to $50 \mathrm{mg}$ ceftiofur.

Animals. Five healthy, 6-9 months-old, female animals of each of cross-breed Friesian calves (weighing 163-209 kg b.wt.) and buffalo calves (weighing 144-351 kg b.wt.) were obtained from the animal farm, Faculty of Veterinary Medicine, Beni-Suef University. Animals were kept under good hygienic condition, feed on hay, concentrated mixture and green fodder and water ad-libitum. None of the animals were treated with antibiotics for one month prior to the study.

Experimental protocol. Two-way crossover design studies were used, with a 2 weeks washout period between successive experiments, where all animals were administered $2.2 \mathrm{mg} \mathrm{kg}^{-1}$ ceftiofur sodium (Folz et al., 1992; Halstead et al., 1992; Mahrt 1992; Meyer et al., 1992; Jaglan et al., 1994; Brown et al., 1995; Brown et al., 1996; Erskine et al., 1996; Courtin et al., 1997; Craigmill et al., 1997; Drew et al., 2004; Chenault et al., 2004; Wenz et al., 2005) as an intravenous bolus and after 2 weeks the animals were given the same dose by an intramuscular route. Blood samples were collected via vein puncture from jugular vein before and 5, 10, 15 and 30 min., 1, 2, 4, 6, 8, 12 and 24 h. postadministration. Blood samples were left to clot for $30 \mathrm{~min}$. then centrifuged at 3000 r.p.m for 15 min. to obtain clear serum that was kept in deep freezer until being assayed. For urine collection each animal was catheterized using a folly balloon catheter No. 16 (Timedco, Atlanta, GA, USA). The urinary bladder was emptied before drug administration. Urine samples were collected prior and at $0.5,1,2,4,6,8,12$ and 24 h. after drug administration. The amount of urine voided at each sampling time was measured and a $10 \mathrm{ml}$ aliquot was stored at $20^{\circ} \mathrm{C}$ until used for assessment.

Drug bioassay. Serum concentrations of ceftiofur sodium were determined by agar welldiffusion microbiological assay according to the method of Bennett et al. (1966) using Micrococcus luteus (American Type Culture Collection ATCC 9341) as an indicator organism (Erskine et al., 1995) and MuellerHinton agar (Oxoid LTD., Basingstoke, Hampshire, England). Standard concentrations of ceftiofur sodium were prepared in antibioticfree calf serum and phosphate buffer saline $(\mathrm{pH}$ 6.2). The standard curves for serum and buffer were linear between 0.6 and $40 \mu \mathrm{g} \mathrm{ml}^{-1}$ ceftiofur sodium with a typical correlation coefficient $>$ 0.99 for serum and buffer. The minimal quantification level for the assay method was 0.6 ug $\mathrm{ml}^{-1}$. The difference of inhibition zone diameter between serum and buffer was used to calculate the in-vitro serum protein-binding tendency of ceftiofur sodium according to (Craig and Suh, 1980) by the following equation:

Protein binding $\%=$

Zone of inhibition in buffer-Zone of inhibition in serum X 100 Zone of inhibition in buffer

Estimation of endogenous creatinine clearance. The creatinine concentrations were measured in serum and urine samples according to the method described by Siest et al. (1985) using a commercial creatinine diagnostic kit (Bio Merieux, Paris, France). The endogenous creatinine and renal clearance $\left(\mathrm{Cl}_{\mathrm{cr}}\right.$ and $\left.\mathrm{Cl}_{\mathrm{R}}\right)$ were calculated according to formulas of Schirmeister et al. (1981):

$\mathrm{Cl}_{\mathrm{cr}}(\mathrm{ml} / \mathrm{min} / 10 \mathrm{~kg} \mathrm{~b} . \mathrm{wt})=$

Creatinine concentration in urine $(\mu \mathrm{g} / \mathrm{ml}) \times$ rate of urine flow $(\mathrm{ml} / \mathrm{min})$

Creatinine concentration in serum $(\mu \mathrm{g} / \mathrm{ml}) \mathrm{x}$ body weight $(\mathrm{kg}) / 10$

$\mathrm{Cl}_{\mathrm{R}}(\min / 10 \mathrm{~kg}$ b.wt. $)=$

Drug concentration in urine $(\mathrm{mg} / \mathrm{dl}) \times$ rate of urine flow $(\mathrm{ml} / \mathrm{min})$

Drug concentration in serum $(\mathrm{mg} / \mathrm{dl}) \mathrm{x}$ body weight $(\mathrm{kg}) / 10$

Ceftiofur sodium clearance and creatinine clearance ratio were calculated according to (Osbaldiston, 1971) to determine the pathway of ceftiofur sodium elimination through the kidney.

Pharmacokinetic analysis. Serum concentrations $\left(\log _{10}\right)$ versus time curve were generated and best fitted by the aid of computer polyexponential curve stripping program (R-strip, Micromath, Scientific software, USA). Data from each animal were fitted individually and the pharmacokinetic variables were computed by the aid of the software program. The hybrid rate constants of distribution and elimination phase ( $\alpha$ and $\beta$ ), first order absorption and elimination rate constants $\left[\mathrm{K}_{\mathrm{ab}}\right.$ and $\left.\mathrm{K}_{\mathrm{el}}\right]$ and the corresponding extrapolated zero time intercepts (A and B), absorption, distribution and elimination half lives $\left(t_{1 / 2(a b),} t_{1 / 2(\alpha)}, t_{1 / 2(\beta)}\right.$ and $\left.t_{1 / 2(e)}\right)$, transfer rate constants $\left(\mathrm{K}_{\mathbf{1 2}}\right.$ and $\left.\mathrm{K}_{21}\right)$, mean residence time (MRT), maximum serum concentration $\left(\mathrm{C}_{\max }\right)$ and time to be achieved $\left(t_{\text {max }}\right)$, volume of central compartment $\left(V_{c}\right)$, apparent volume of distribution at steady state 
$\left(\mathrm{Vd}_{\mathrm{ss}}\right)$, total body clearance $\left(\mathrm{Cl}_{\mathbf{B}}\right)$ were calculated according to Baggot (1978). Area under the serum concentration-time curve (AUC) was calculated by trapezoidal rule, whereas the intramuscular bioavailability (F) was calculated according to the following equation: (AUC i.m /AUC i.v) x 100, (Gibaldi and Perrier 1982). The statistical analysis were carried out according to (Snedecor and Cochran 1976).

The serum concentration-time curves following intravenous and intramuscular administration of $2.2 \mathrm{mg} \mathrm{kg}^{-1} \mathrm{~b}$.wt of ceftiofur sodium in Friesian and buffalo calves are shown (Fig.1,2). Following i.v administration, the serum concentration-time curves obeyed two-compartments open model in both Friesian and buffalo calves. The pharmacokinetic parameters were summarized (Table1). Ceftiofur sodium was distributed in buffalo calves significantly $(\mathrm{p}<0.05)$ faster rate than in cattle calves as evidenced by long distribution rate constant $(\alpha)$ $3.949 \mathrm{~h}^{-1}$ and short distribution half-life $\left(\mathrm{t}_{1 / 2(\alpha)}\right)$ $0.176 \mathrm{~h}$. in buffalo calves compared to $1.804 \mathrm{~h}^{-1}$ and 0.384 h., respectively in Friesian calves.

Small volumes of the central compartment $\left(V_{c}\right) 0.132$ and $0.076 \mathrm{~L} \mathrm{~kg}^{-1}$ and of distribution $\left(\mathrm{Vd}_{\mathrm{ss}}\right) 0.206$ and $0.134 \mathrm{~L} \mathrm{~kg}^{-1}$ were obtained in Friesian and buffalo calves, respectively. The results indicated a limited distribution of the drug. The drug was eliminated at slower rate in Friesian calves $(p<0.01)$ than in buffalo calves as indicated by long elimination half-lives $\left(t_{1 / 2(\beta)}\right)$ $5.047 \mathrm{~h}$. compared to $1.607 \mathrm{~h}$., respectively. Table (2) shows the resulting pharmacokinetic parameters following intramuscular administration. The concentrations in serum reached a peak at a significant $(p<0.01)$ long time $\left(t_{\max }\right)$ of 3.147 in Friesian calves compared to $0.825 \mathrm{~h}$. in buffalo calves and the respective $\mathrm{C}_{\max }$ values were 5.539 and $9.663 \mathrm{ug} \mathrm{ml}^{-1}$, respectively. Ceftiofur sodium was absorbed in buffalo calves in significantly $(p<0.01)$ faster rate compared with Friesian calves as indicated by long absorption rate constant $\left(\mathrm{k}_{\mathbf{a b}}\right) 3.200 \mathrm{~h}^{-1}$ and short absorption half-life $\left(\mathrm{t}_{1 / 2(a b)}\right) 0.217 \mathrm{~h}$. in buffalo calves compared to $0.686 \mathrm{~h}^{-1}$ and $1.010 \mathrm{~h}$. in Friesian calves, respectively. Elimination halflives of 5.239 and 1.750 h., systemic bioavailabilities of 89.82 and $99.7 \%$ and serum protein-binding tendencies of 39.68 and $14.44 \%$ were recorded in Friesian and buffalo calves, respectively. Ceftiofur sodium was found to be excreted at high concentrations in urine of
Friesian and buffalo calves following both i.v. and i.m. routes and extends up to $24 \mathrm{~h}$. in Friesian calves and 8-12 h. in buffalo calves post-administration (Table 3). Also the ceftiofur sodium to creatinine clearance was less than one (Tables 4, 5).

\section{Discussion}

Interpretation of results of the present study takes into consideration the assay method used (microbiological) and its sensitivity. The microbiological assay method did not, however distinguish between the parent drug (ceftiofur) and its active metabolite (desfuroylceftiofur). The presence of active metabolite may not necessarily interfere with determination of a therapeutic dosage regimen (Sams, 1994 and Gavrielli et al., 1995). Cephalosporins offer the advantages of low toxicity and a broad antimicrobial spectrum (Caprile, 1988). Ceftiofur sodium is favored due to its wide range of antimicrobial therapy and its long storage stability after reconstitution, 7 days when refrigerated and frozen reconstituted solutions are stable for up to 8 weeks (Plumb, 1995). Following intravenous administration of ceftiofur sodium to Friesian and buffalo calves at a dose of $2.2 \mathrm{mg} \mathrm{kg}-1$., the drug concentrationtime data for each animal was best fitted individually using a two-compartment open model. A similar kinetic profile was recorded in dairy cattle (Whittem et al., 1995), calves (Halstead et al., 1992; Vermeersch et al., 1996), dairy goats (Courtin et al., 1997) and sheep (Craigmill et al., 1997).

Disappearance of the drug from the serum of Friesian and buffalo calves was characterized by slower $(p<0.05)$ distribution phases $\left(t_{1 / 2(\alpha)}\right)$ and slower $(p<0.01)$ elimination phases $\left(t_{1 / 2(\beta)}\right)$ in Friesian calves than in buffalo calves as indicated by values of 0.384 and $5.047 \mathrm{~h}$. vs. 0.176 and $1.607 \mathrm{~h}$., respectively. This result may be due to lower serum protein binding tendency of the drug in buffalo than Friesian calves. The result of $t_{1 / 2(\alpha)}$ in Friesian $(0.384$ h.) is nearly similar to those recorded in sheep $0.457 \mathrm{~h}$. (Craigmill et al., 1997) and dairy goats $0.470 \mathrm{~h}$. (Courtin et al., 1997). While, the $\mathrm{t}_{1 / 2(\alpha)}$ in buffalo calves $0.176 \mathrm{~h}$. is nearly similar to that reported in sheep $0.108 \mathrm{~h}$. (Craigmill et al., 1997). Ceftiofur sodium has been shown to have a relatively long elimination half-life similar to that reported in cattle 7.12 and $6.6 \mathrm{~h}$. (Soback et al., 1991 and Whittem et al., 1995), calves $3.2 \mathrm{~h}$. (Vermeersch et al., 1996), dairy goats 2.86$4.23 \mathrm{~h}$.(Courtin et al., 1997) and sheep 4-5.83 h. 
Table (1): Mean $( \pm$ SE) kinetic parameters of ceftiofur sodium following a single intravenous administration of $2.2 \mathrm{mg} \mathrm{kg}^{-1}$ b.wt in Friesian and buffalo calves $(n=5)$.

\begin{tabular}{cccc}
\hline Parameter & Unit & Friesian calves & Buffalo calves \\
\hline $\mathrm{C}_{\mathrm{p}}{ }^{\mathrm{N}}$ & $\mu \mathrm{g} \mathrm{ml}^{-1}$ & $16.604 \pm 1.28$ & $28.929 \pm 1.9^{* *}$ \\
$\mathrm{~A}$ & $\mu \mathrm{g} \mathrm{ml}^{-1}$ & $7.009 \pm 0.459$ & $16.006 \pm 1.40^{*}$ \\
$\mathrm{~B}$ & $\mu \mathrm{g} \mathrm{m}^{-1}$ & $9.595 \pm 0.561$ & $12.922 \pm 1.16$ \\
$\alpha$ & $\mathrm{h}^{-1}$ & $1.804 \pm 0.097$ & $3.949 \pm 0.263 * *$ \\
$\beta$ & $\mathrm{h}^{-1}$ & $0.137 \pm 0.040$ & $0.431 \pm 0.071^{*}$ \\
$\mathrm{k}_{21}$ & $\mathrm{~h}^{-1}$ & $1.100 \pm 0.079$ & $2.003 \pm 0.099^{* *}$ \\
$\mathrm{~K}_{\mathrm{el}}$ & $\mathrm{h}^{-1}$ & $0.225 \pm 0.011$ & $0.851 \pm 0.046^{* *}$ \\
$\mathrm{k}_{12}$ & $\mathrm{~h}^{-1}$ & $0.616 \pm 0.069$ & $1.527 \pm 0.078^{* *}$ \\
$\mathrm{t}_{1 / 2(\alpha)}$ & $\mathrm{h}$ & $0.384 \pm 0.071$ & $0.176 \pm 0.022^{*}$ \\
$\mathrm{t}_{1 / 2(\beta)}$ & $\mathrm{h}$ & $5.047 \pm 0.399$ & $1.607 \pm 0.066^{* *}$ \\
$\mathrm{MRT}_{\mathrm{AUC}}$ & $\mathrm{h}$ & $6.926 \pm 0.477$ & $2.072 \pm 0.092^{* *}$ \\
$\mathrm{AUMC}$ & $\mu \mathrm{g} \mathrm{ml}^{-1} \mathrm{~h}^{-1}$ & $75.38 \pm 9.224$ & $34.812 \pm 2.98^{*}$ \\
$\mathrm{Vc}$ & $\mu \mathrm{g} \mathrm{ml}^{-1} \mathrm{~h}^{-1}$ & $510.77 \pm 41.5$ & $70.470 \pm 8.01 * *$ \\
$\mathrm{Vd}_{\mathrm{ss}}$ & $\mathrm{L} \mathrm{kg}^{-1}$ & $0.132 \pm 0.077$ & $0.076 \pm 0.004$ \\
$\mathrm{Cl}_{\mathrm{B}}$ & $\mathrm{L} \mathrm{kg}^{-1}$ & $0.206 \pm 0.032$ & $0.134 \pm 0.024$ \\
\hline $\mathrm{L} \mathrm{kg}^{-1} \mathrm{~h}^{-1}$ & $0.029 \pm 0.008$ & $0.065 \pm 0.001 *$ \\
\hline
\end{tabular}

$* \mathrm{p}<0.05 * * \mathrm{p}<0.01$

$\mathrm{C}_{\mathrm{p}}{ }^{\mathrm{o}}$ ceftiofur concentration at zero time; A, B zero-time intercepts of the biphasic disposition curve; $\alpha, \beta$ hybrid rate constants representing the slopes of distribution and elimination phases, respectively; $\mathrm{k}_{21}$ first-order constant for transfer from peripheral to central compartment; $\mathrm{K}_{\mathrm{el}}$ elimination rate constant; $\mathrm{k}_{12}$ first-order constant for transfer from central to peripheral compartment; $t_{1 / 2(\alpha)}$ distribution half-life; $t_{1 / 2(\beta)}$ elimination half-life; MRT mean residence time; AUC area under curve; AUMC area under moment curve; Vc apparent volume of the central compartment; $\mathrm{Vd}_{\mathrm{ss}}$ volume of distribution at steady state; $\mathrm{Cl}_{\mathrm{B}}$ total body clearance.

Table (2): Mean ( \pm SE $)$ kinetic parameters of ceftiofur sodium following a single intramuscular administration of $2.2 \mathrm{mg} \mathrm{kg}^{-1}$ b.wt in Friesian and buffalo calves $(\mathrm{n}=5)$.

\begin{tabular}{cccc}
\hline Parameter & Unit & Friesian calves & Buffalo calves \\
\hline $\mathrm{k}_{\mathrm{ab}}$ & $\mathrm{h}^{-1}$ & $0.686 \pm 0.043$ & $3.200 \pm 0.196^{* *}$ \\
$\mathrm{~K}_{\mathrm{el}}$ & $\mathrm{h}^{-1}$ & $0.132 \pm 0.025$ & $0.396 \pm 0.053^{* *}$ \\
$\mathrm{t}_{1 / 2(\mathrm{ab})}$ & $\mu \mathrm{g} \mathrm{m}{ }^{-1}$ & $1.010 \pm 0.088$ & $0.217 \pm 0.033^{* *}$ \\
$\mathrm{t}_{1 /(\mathrm{el})}$ & $\mathrm{h}$ & $5.239 \pm 0.308$ & $1.750 \pm 0.083^{* *}$ \\
$\mathrm{C}_{\max }$ & $\mathrm{h}$ & $5.539 \pm 0.471$ & $9.663 \pm 0.083^{* *}$ \\
$\mathrm{t}_{\max }$ & $\mathrm{h}$ & $3.147 \pm 0.345$ & $0.825 \pm 0.057 * *$ \\
$\mathrm{AUC}$ & $\mu \mathrm{h} \mathrm{ml}^{-1} \mathrm{~h}^{-1}$ & $67.712 \pm 4.98$ & $34.700 \pm 1.85^{* *}$ \\
$\mathrm{AUMC}$ & $\mu \mathrm{g} \mathrm{ml}^{-1} \mathrm{~h}^{-1}$ & $559.17 \pm 39.5$ & $92.94 \pm 7.730^{* *}$ \\
$\mathrm{MRT}$ & $\mathrm{h}$ & $9.015 \pm 0.492$ & $2.837 \pm 0.194 * *$ \\
$\mathrm{~F}$ & $\%$ & $89.82 \pm 6.761$ & $99.7 \pm 7.009$ \\
\hline
\end{tabular}

$* * \mathrm{p}<0.01$

Protein binding $\%$ in Friesian calves was $39.68+3.07$ and $14.44 \pm 0.89$ in buffalo calves. $\mathrm{k}_{\mathrm{ab}}$ first-order absorption rate constant; $\mathrm{K}_{\mathrm{el}}$ first-order elimination rate constant; $\mathrm{C}_{\max }$ maximum serum concentration; $\mathrm{t}_{\max }$ time to peak serum concentration; $\mathrm{t}_{0.5(\mathrm{ab})}$ absorption half-life; $\mathrm{t}_{0.5(\mathrm{el})}$ elimination half-life; $\mathrm{F}$ fraction of drug absorbed systemically after i.m injection. 

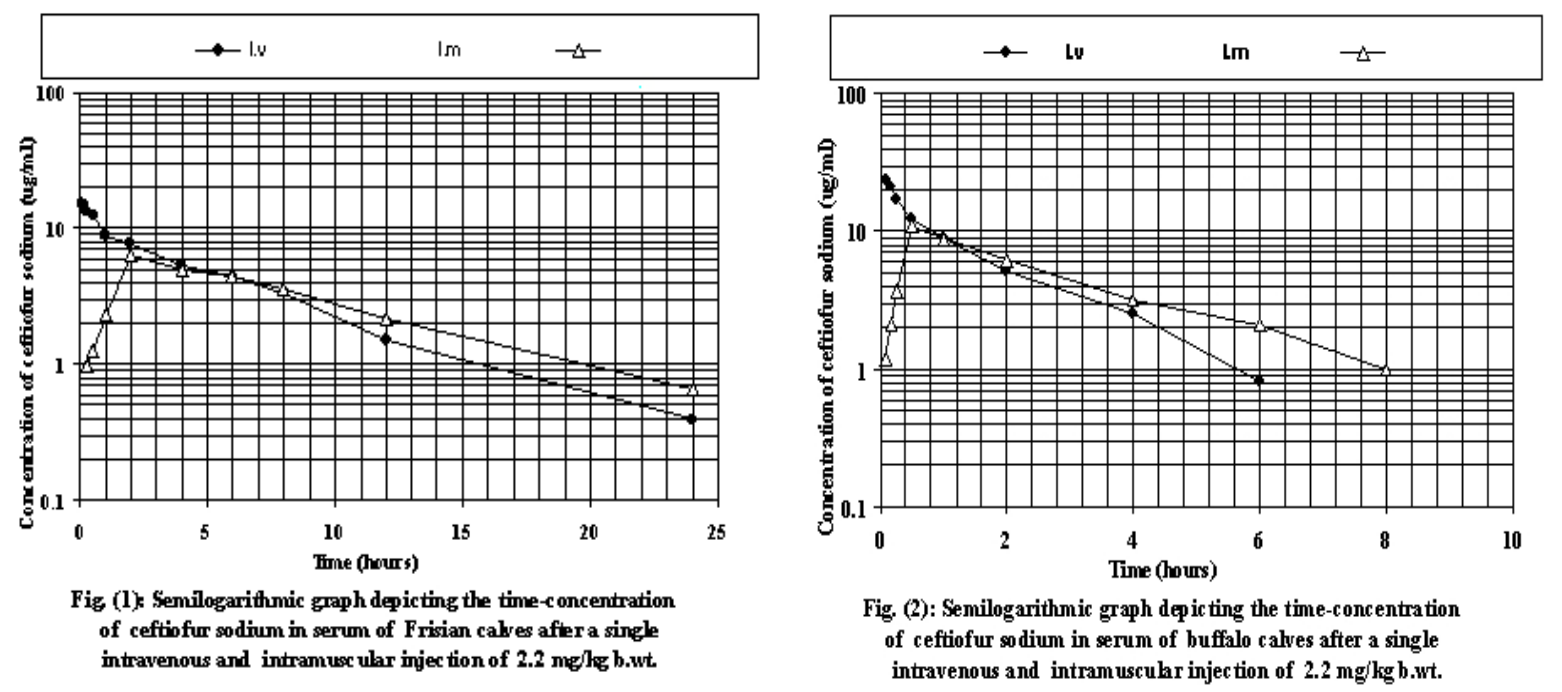

Table (3): Urine concentration of ceftiofur sodium following intravenous (i.v) and intra-muscular (i.m) administration of $2.2 \mathrm{mg} \mathrm{kg}^{-1}$ b.wt. in Friesian and buffalo calves $(\mathrm{n}=5)$.

\begin{tabular}{|c|c|c|c|c|}
\hline \multirow{3}{*}{ Time (h) } & \multicolumn{4}{|c|}{ Urine concentration of ceftiofur sodium $\mu \mathrm{g} \mathrm{ml}^{-1}($ Mean $\pm \mathrm{SE})$} \\
\hline & \multicolumn{2}{|c|}{ Friesian calves } & \multicolumn{2}{|c|}{ Buffalo calves } \\
\hline & i.v & i.m & i.v & i.m \\
\hline 0.5 & $127.4 \pm 10.2$ & $86.18 \pm 7.3$ & $243.0 \pm 22.4$ & $178.2 \pm 17.3$ \\
\hline 1 & $192.1 \pm 15.6$ & $105.1 \pm 9.5$ & $466.3 \pm 44.6$ & $330.1 \pm 31.4$ \\
\hline 2 & $288.9 \pm 22.4$ & $167.4 \pm 13.4$ & $263.9 \pm 28.0$ & $198.2 \pm 17.6$ \\
\hline 4 & $211.4 \pm 18.7$ & $136.3 \pm 12.7$ & $163.1 \pm 14.6$ & $112.8 \pm 9.12$ \\
\hline 6 & $168.7 \pm 19.1$ & $109.2 \pm 9.5$ & $96.3 \pm 8.07$ & $79.45 \pm 7.03$ \\
\hline 8 & $139.3 \pm 14.2$ & $85.8 \pm 9.61$ & $9.36 \pm 0.77$ & $26.34 \pm 3.21$ \\
\hline 12 & $74.46 \pm 7.34$ & $43.42 \pm 6.10$ & $\overline{\mathrm{B}}$ & $5.11 \pm 0.20$ \\
\hline 24 & $4.65+0.185$ & $7.04+0.42$ & B & $\overline{\mathrm{B}}$ \\
\hline
\end{tabular}

*B:Below the limit of the sensitivity of the assay method used.

Table (4): Ceftiofur sodium / creatinine clearance ratio following intravenous and intramuscular administration of ceftiofur sodium at a dose of $2.2 \mathrm{mg} \mathrm{kg}^{-1} \mathrm{~b}$.wt. in Friesian calves $(\mathrm{n}=5)$.

\begin{tabular}{|c|c|c|c|c|c|c|}
\hline \multirow[b]{2}{*}{ Time (h) } & \multicolumn{3}{|c|}{ i.v } & \multicolumn{3}{|c|}{ i.m } \\
\hline & $\begin{array}{l}\text { Ceftiofur sod. } \\
\text { clearance ml } \\
\min ^{-1} 10 \mathrm{~kg}^{-1}\end{array}$ & $\begin{array}{l}\text { Creatinine } \\
\text { clearance } \mathrm{ml} \\
\mathrm{min}^{-1} 10 \mathrm{~kg}^{-1}\end{array}$ & Ratio & $\begin{array}{l}\text { Ceftiofur sod. } \\
\text { clearance ml } \\
\text { min }^{-1} 10 \mathrm{~kg}^{-1}\end{array}$ & $\begin{array}{l}\text { Creatinine } \\
\text { clearance } \mathrm{ml} \\
\mathrm{min}^{-1} 10 \mathrm{~kg}^{-1}\end{array}$ & Ratio \\
\hline 0.5 & $2.93 \pm 0.12$ & $18.69 \pm 1.3$ & $0.157 \pm 0.07$ & $6.46 \pm 0.052$ & $7.00 \pm 0.54$ & $0.923 \pm 0.07$ \\
\hline 1 & $2.42+0.17$ & $11.69 \pm 0.91$ & $0.207 \pm 0.02$ & $3.74+0.18$ & $9.71 \pm 0.88$ & $0.385 \pm 0.02$ \\
\hline 2 & $3.63+0.22$ & $11.36+1.01$ & $0.320+0.01$ & $1.57+0.21$ & $9.72+0.65$ & $0.162+0.04$ \\
\hline 4 & $3.79 \pm 0.19$ & $11.96 \pm 1.37$ & $0.317 \pm 0.04$ & $1.50 \pm 0.09$ & $6.93 \pm 0.34$ & $0.216 \pm 0.06$ \\
\hline 6 & $1.78+0.08$ & $6.18+0.53$ & $0.288+0.06$ & $0.87 \pm 0.03$ & $3.29 \pm 0.21$ & $0.264 \pm 0.03$ \\
\hline 8 & $1.18+0.06$ & $5.04+0.34$ & $0.234+0.06$ & $0.58+0.01$ & $3.52+0.22$ & $0.165 \pm 0.04$ \\
\hline 12 & $1.84+0.10$ & $6.01+0.61$ & $0.306+0.07$ & $1.12+0.09$ & $5.85+0.36$ & $0.191+0.02$ \\
\hline
\end{tabular}

ND:Not detected.

Table (5): Ceftiofur sodium / creatinine clearance ratio following intravenous and intramuscular administration of ceftiofur sodium at a dose of $2.2 \mathrm{mg} \mathrm{kg}^{-1} \mathrm{~b} . w \mathrm{t}$. in buffalo calves $(\mathrm{n}=5)$.

\begin{tabular}{|c|c|c|c|c|c|c|}
\hline \multirow[b]{2}{*}{ Time (h) } & \multicolumn{3}{|c|}{ i.v } & \multicolumn{3}{|c|}{ i.m } \\
\hline & $\begin{array}{l}\text { Ceftiofur sod. } \\
\text { clearance ml } \\
\text { min }^{-1} 10 \mathrm{~kg}^{-1}\end{array}$ & $\begin{array}{l}\text { Creatinine } \\
\text { clearance ml } \\
\text { min }^{-1} 10 \mathrm{~kg}^{-1}\end{array}$ & Ratio & $\begin{array}{l}\text { Ceftiofur sod. } \\
\text { clearance ml } \\
\text { min-1 }^{-1} 10 \mathrm{~kg}^{-1}\end{array}$ & $\begin{array}{c}\text { Creatinine } \\
\text { clearance ml } \\
\min ^{-1} 10 \mathrm{~kg}^{-1}\end{array}$ & Ratio \\
\hline 0.5 & $1.58 \pm 0.08$ & $10.12 \pm 0.9$ & $0.156 \pm 0.03$ & $2.43 \pm 0.10$ & $15.11 \pm 1.14$ & $0.161 \pm 0.02$ \\
\hline 1 & $3.19 \pm 0.41$ & $5.82 \pm 0.36$ & $0.548+0.07$ & $1.94 \pm 0.21$ & $6.94 \pm 0.74$ & $0.280 \pm 0.04$ \\
\hline 2 & $3.00 \pm 0.34$ & $5.80 \pm 0.55$ & $0.517 \pm 0.06$ & $1.19 \pm 0.30$ & $4.51 \pm 0.61$ & $0.264 \pm 0.05$ \\
\hline 4 & $6.20 \pm 0.70$ & $6.26+0.34$ & $0.990+0.08$ & $2.46+0.19$ & $6.96 \pm 0.68$ & $0.353 \pm 0.04$ \\
\hline 6 & $4.40 \pm 0.35$ & $9.22 \pm 0.77$ & $0.477 \pm 0.06$ & $1.54 \pm 0.17$ & $3.94 \pm 0.044$ & $0.391 \pm 0.07$ \\
\hline 8 & ND & $0.62 \pm 0.08$ & - & $1.35 \pm 0.31$ & $5.00 \pm 0.67$ & $0.270 \pm 0.01$ \\
\hline 12 & ND & $4.52+0.37$ & - & ND & $7.05 \pm 0.35$ & - \\
\hline
\end{tabular}

ND:Not detected. 
(Craigmill et al., 1997).

The volume of distribution at steady-state $\left(\mathrm{Vd}_{\mathrm{ss}}\right)$ is an accurate indication of the diffusion of the drug into the body tissues (Gilman et al., 1980; Galinsky and Svensson, 1995). The small volumes of distribution of ceftiofur sodium at steady-state $\left(\mathrm{Vd}_{\mathrm{ss}}\right) 0.206$ and $0.134 \mathrm{~L} \mathrm{~kg}^{-1}$ in Friesian and buffalo calves, respectively, indicating poor distribution of the drug to the extra-vascular tissues. This poor distribution is probably due to its poor lipid solubility and relatively low pka (Amer et al., 1998). These values were close to the values reported in dairy cattle $0.200 \mathrm{~L} \mathrm{kg-1}$ (Whittem et al., 1995), calves 0.284-0.345 L kg-1 (Brown et al., 1996) and dairy goats $0.25-0.31 \mathrm{~L} \mathrm{~kg}-1$ (Courtin et al., 1997). The drug has been showed a significant longer mean residence time (MRT) $(\mathrm{p}<0.01)$ in Friesian calves $6.926 \mathrm{~h}$. than in buffalo calves $2.072 \mathrm{~h}$. The result in Friesian calves was supported by those recorded in dairy cattle 6.48 h. (Whittem et al., 1995) and sheep 5.75-7.38 h. (Craigmill et al., 1997).

In the present study, the total body clearance $\left(\mathrm{Cl}_{\mathrm{B}}\right)$ of ceftiofur sodium was very slow in Friesian and buffalo calves $(0.030$ and $0.065 \mathrm{~L} \mathrm{~kg}^{-1} \mathrm{~h}^{-1}$ ), indicating that ceftiofur excretion is not only by glomerular filtration but also by extra-renal pathway (Soback et al., 1989). These values were similar to that reported in dairy cattle $0.032 \mathrm{~L} \mathrm{~kg}^{-1} \mathrm{~h}^{-1}$ (Whittem et al., 1995), dairy goats $0.067-0.089 \mathrm{~L} \mathrm{~kg}^{-1} \mathrm{~h}^{-1}$ (Courtin et al., 1997) and calves $0.0167 \mathrm{~L} \mathrm{~kg} \mathrm{~h}^{-1}$ (Brown et al., 1996). The drug cleared at a significant faster rate $(\mathrm{p}<0.05)$ in buffalo calves than in Friesian calves as indicated by large $\mathrm{Cl}_{\mathrm{B}}$ in buffalo calves $0.065 \mathrm{~L} \mathrm{~kg}^{-1} \mathrm{~h}^{-1}$ compared to $0.030 \mathrm{~L} \mathrm{~kg}^{-1} \mathrm{~h}^{-1}$ in Friesian calves. This result may be attributed to the lower protein binding capacity of the drug in buffalo calves than in Friesian calves.

Following intramuscular administration, the peak concentrations $\left(\mathrm{C}_{\max }\right)$ achieved with $2.2 \mathrm{mg}$ kg-1 dose were $5.539 \mu \mathrm{g} \mathrm{ml}^{-1}$ in Friesian calves and $9.663 \mathrm{ug} \mathrm{ml}^{-1}$ in buffalo calves. The value of $\mathrm{C}_{\max }$ in buffalo calves is similar to those recorded in calves $8.8 \mu \mathrm{g} \mathrm{ml}^{-1}$ (Halstead et al., 1992) and sheep $7.13 \mu \mathrm{g} \mathrm{ml}^{-1}$ (Craigmill et al., 1997). Also the value of $C_{\max }$ in Friesian calves is similar to those recorded in dairy goats 4.57 ug $\mathrm{ml}^{-1}$ (Courtin et al., 1997) and sheep $4.33 \mu \mathrm{g}$ $\mathrm{ml}^{-1}$ (Craigmill et al., 1997). This study show that ceftiofur sodium was absorbed at a faster rate $(\mathrm{p}<0.01)$ in buffalo calves than Friesian calves as indicated by a doubling of $\mathrm{C}_{\max } 9.663$ $\mu \mathrm{g} \mathrm{ml}{ }^{-1}$ and short absorption half-life $\left(t_{1 / 2(a b)}\right)$ $0.217 \mathrm{~h}$. in buffalo calves as compared to 5.539 $\mu \mathrm{g} \mathrm{ml} \mathrm{m}^{-1}$ and $1.010 \mathrm{~h}$. in Friesian calves. This result was supported by the lower protein binding capacity of the drug in buffalo calves than in Friesian calves. Peak serum concentration attained at a shorter $(p<0.01)$ time (tmax) $0.825 \mathrm{~h}$. in buffalo calves than in Friesian calves $3.147 \mathrm{~h}$.

Absorption of ceftiofur sodium was rapid in buffalo calves than in Friesian calves as indicated by large absorption rate constant $\left(\mathrm{k}_{\mathrm{ab}}\right)$ $3.200 \mathrm{~h}^{-1}$ and short absorption half-life $\left(\mathrm{t}_{1 / 2(\mathrm{ab})}\right)$ $0.217 \mathrm{~h}$. compared to $0.686 \mathrm{~h}^{-1}$ and $1.010 \mathrm{~h}$., respectively. The $t_{1 / 2(a b)}$ in buffalo calves is similar to that in dairy goats $0.20-0.27 \mathrm{~h}$. (Courtin et al., 1997).

Ceftiofur sodium was eliminated at slower rate $(p<0.01)$ in Friesian calves than in buffalo calves as indicated by long elimination half-lives $\left(\mathrm{t}_{1 / 2 \mathrm{el})}\right)$ and mean residence time (MRT) in Friesian calves $5.239 \mathrm{~h}$. and $9.015 \mathrm{~h}$. compared to $1.750 \mathrm{~h}$. and $2.837 \mathrm{~h}$. in buffalo calves. The previously mentioned results of $t_{1 / 2(\mathrm{el})}$ and MRT in Friesian calves are close to values recorded in sheep 6.48-7.65 h. and 7.85-9 h. (Craigmill et al., 1997).

Intramuscular bioavailability of ceftiofur sodium was $89.82 \%$ in Friesian calves and 99.7 $\%$ in buffalo calves, reflexing good absorption of the drug from the site of i.m injection. These values are similar to that recorded in dairy goats and sheep $100 \%$ (Courtin et al., 1997; Craigmill et al., 1997). Bioavailability of ceftiofur sodium is complete in calves after intramuscular injection (Brown et al., 1996). Serum proteinbinding capacity of the drug is significantly higher $(p<0.01)$ in Friesian calves than in buffalo calves as indicated by a percent of binding 39.68 $\%$ in Friesian calves compared to $14.14 \%$ in buffalo calves.

The higher concentrations of ceftiofur sodium were found in urine, indicating that the drug may be an efficacious drug for treating urinary tract infections caused by susceptible microorganisms. The ratios between ceftiofur clearance to creatinine clearance was less than one, indicating that the glomerular filtration is the main pathway for ceftiofur elimination through the kidney. This finding was in agreement with results reported for other $4^{\text {th }}$ generation cephalosporin (cefepime) in humans (Barbhaiya et al., 1992; Kalman et al. 1992), Friesian calves (Ismail, 2005a) and ewes (Ismail, 2005b). 
Ceftiofur sodium has been shown to have excellent in vitro activity against a variety of gram-negative veterinary respiratory pathogens such as $P$. haemolytica, P. multocida, H. somnus and Escherichia coli (Yancey et al., 1987; Watts et al., 1994; Salmon et al., 1995).

The minimum inhibitory concentration (MIC90) of the drug for $P$. haemolytica, $P$. multocida and H.somnus was $<0.03 \mathrm{ug} \mathrm{ml}^{-1}$ (Salmon et al., 1996). Its $\mathrm{MIC}_{90 \mathrm{~s}}$ for Actinobacillus pleuropneumonia, Haemolytic streptococci, Klebsiella pneumoniae and E. coli were in the range of $<0.03-1 \mu \mathrm{g} \mathrm{m}^{-1}$ (Salmon et al., 1996; Deshpande et al., 2000).

\section{Conclusion}

Based on the pharmacokinetic parameters observed in this study and if we make a relationship between the concentrations of ceftiofur sodium in serum and urine with the $\mathrm{MIC}_{90 \mathrm{~s}}$ of microorganisms isolated from other animal species, dosage regimen of $2.2 \mathrm{mg} \mathrm{kg}^{-1}$ administered two times daily in Friesian calves and three times daily in buffalo calves could be an appropriate choice for the treatment of calves with respiratory tract infections caused by $P$. haemolytica, P. multocida and $H$. somnus. Also, such dosage regimen can be used for treatment of other infections in calves caused by the susceptible microorganisms.

\section{References}

Amer, A. M. M..; Fahim, E. M. M. and Ibrahim, R. K. (1998): Effect of aflatoxicosis on the kinetic behaviour of ceftiofur in chickens. J. Vet. Med., Giza, 46(1): 17-27.

Anonymous (1991): Naxel brand of ceftiofur sodium sterile powder, manufacture's product information. The Upjohn Company, Kalamazoo, MI.

Baggot, J. D. (1978): Some aspects of clinical pharmacokinetics in veterinary medicine. J. Vet. Pharmacol. Therap., 1: 5-17.

Barbhaiya, R. H.; Forgue, S. T. ; Gleason, C. R.; Knupp, C. A.; Pittman, K. A. ; Weidler, D. J.; Movahhed, H.; Tenny, J. and Martin, R. P. (1992): Pharmacokinetics of cefepime after single and multiple intravenous administration in healthy subjects. Antimicrob. Agents Chemother., 36 (1): 552-557.

Bennett, J. V.; Brodie, J. L.; Benner, E. J. and Kirby, W. M. M (1966): Simplified, accurate method for antibiotic assay of clinical specimens. Applied Microbiol., 14 (2): 170-177.

Brown, S. A.; Arnold, T. S.; Hamlow, P. J.; Speedy, A. K.; Deleeuw, N. L.; Hubbard, V. L.; Callahan, J. K.; Folz, S. D.; Janose, R. L. and Flook, T. F. (1995): Plasma and urine disposition and dose proportionality of ceftiofur and metabolites in dogs after subcutaneous administration of ceftiofur sodium. J. Vet. Pharmacol. Ther., 18 (5): 363-9. Brown, S. A.; Chester, S. T. and Robb, E. J. (1996): Effects of age on the pharmacokinetics of single dose ceftiofur sodium administered intramuscularly or intravenously to cattle. J. Vet. Pharmacol. Ther., 19(1): 328.
Brown, S. A.; Jaglan, P. S. and Banting, A. (1991): Ceftiofur sodium: disposition, protein binding, metabolism and residue depletion profile in various species. Acta Veterinaria Scandinavica, Suppl., 87, 97-99.

Caprile, K. (1988): The cephalosporin antimicrobial agents: A comprehensive review. Journal of Veterinary Pharmacology and Therapeutics, 11: 1-32.

Chenault, J. R.; McAllister, J. F.;Chester, S. T.; Dame, K. J.; Kausche, F. M. and Robb, E. J. (2004): Efficacy of ceftiofur hydrochloride sterile suspension administered parenterally for the treatment of acute postpartum metritis in dairy cows. J. Am. Vet. Med. Assoc., 224(10): 1634-9.

Clarke, C. R.; Brown, S. A.; Streeter, R. N.; Clarke, J. M.; Hamlow, P. J.; Callahan, J. K.; Hubbard, V. L.; Speedy, A. K. and Burrows, G. E. (1996): Penetration of parentrally administered ceftiofur into sterile vs. Pasteurella haemolytica-infected tissue chambers in cattle. J. Vet. Pharmacol. Ther., 19: 376-381.

Courtin, F.; Craigmill, A. L.; Wetzlich, S. E.; Gustafson, C. R. and Arndt, T. S. (1997): Pharmacokinetics of ceftiofur and metabolites after single intravenous and intramuscular administration and multiple intramuscular administrations of ceftiofur sodium to dairy goats. J. Vet. Pharmacol. Ther., 20: 368-373.

Courtin, F.; Wetzlich, S. E.; Gustafson, C. R. and Craigmill, A. L. (1994): Pharmacokinetics and milk residues of ceftiofur and metabolites in dairy goats. Proceedings of the $6^{\text {th }}$ EAVPT International Congress, Edinburgh, Scotland, 7-11 August 1994. Blackwell Scientific Publications, Edinburgh, pp. 81-82.

Craig, A. W. and Suh, B. (1980): Protein binding and the antibacterial effects: Methods for determination of protein binding. In: V. Lorian (ed.), Antibiotics in Laboratory Medicine, (Williams and Wilkins, Baltimore, MD), pp. 265-297.

Craigmill, A. L.; Brown, S. A.; Wetzlich, S. E.; Gustafson, C.R. and Arndt, T.S. (1997): Pharmacokinetics of ceftiofur and metabolites after single intravenous and intramuscular administration and multiple intramuscular administrations of ceftiofur sodium to sheep. J. Vet. Pharmacol. Therap., 20: 139-144.

Craigmill, A. L.; Wetzlich, S. E.; Bulgin, M. and Lane, M. (1991): Pharmacokinetics of ceftiofur in sheep. Acta Veterinaria Scandinavica, Suppl., 87: 120-122.

Crosier, K.; Riviere, J. E. and Craigmill, A. L. (1996): FARAD Comprehensive Compendium of Food Animal Drugs. $10^{\text {th }}$ ed, University of Florida Cooperative Extension Service.

Deshpande, L.; Pfaller, M. A. and Jones, R. N. (2000): In vitro activity of ceftiofur tested against clinical isolates of Escherichia coli and Klebsiella pneumoniae including extended spectrum $\beta$-lactamase producing strains. International J. Antimicrob. Agents, 15: 271-275.

Drew, M. L.; Johnson, L.; Pugh, D.; Navarre, C. B.; Taylor, I. T. and Craigmill, A. L (2004): Pharmacokinetics of ceftiofur in llamas and alpacas. J. Vet. Pharmacol. Ther., 27 (1): 13-20.

Erskine, R. J.; Bartlett, P. C.; Johnson, G. L. and Halbert, L. W. (1996): Intramuscular administration of ceftiofur sodium versus intramammary infusion of penicillin/ novobiocin for treatment of Streptococcus agalactiae mastitis in dairy cows. J. Am. Vet. Med. Assoc., 208(2): 258-60.

Erskine, R. J.; Wilson, R. C.; Tyler, J. W.; McClure, K. A.; Nelson, R. S. and Spears, H. J. (1995): Ceftiofur distribution in serum and milk from clinically normal cows 
and cows with experimental Escherichia coli-induced mastitis. Am. J. Vet. Res., 56 (4): 481-5.

Folz, S. D.; Hanson, B. J.; Griffin, A. K.; Dinvald, L. L.; Swerczek, T. W.; Walker, R. D. and Foreman, J. H. (1992): Treatment of respiratory infections in horses with ceftiofur sodium. Equine Vet. J., 24 (4): 300-304.

Galinsky, R. E. and Svensson, C. K. (1995): Basic pharmacokinetics. In: J.P. Remington (ed.), the science and Practice of Pharmacy, $19^{\text {th }}$ ed., (Mack Publishing Company, Easton, PA), pp.724-740.

Gavrielli, R.; Yagil, R.; Ziv, G.; Creveld, C. and Glickman, A. (1995): Effect of water deprivation on the disposition kinetics of enrofloxacin in camels. Journal of Veterinary Pharmacology and Therapeutics, 18: 333-339.

Gibaldi, M. and Perrier, D. (1982): Pharmacokinetics, $2^{\text {nd }}$ ed. Marcel Dedder, New York.

Gilman, A. G.; Goodman, L. S. and Ghman, A. (1980): Goodman and Gilman's: The pharmacological basis of therapeutics, $6^{\text {th }}$ ed. (New York, MacMillian), pp. 21.

Halstead, S. L.; Walker, R. D.; Baker, J. C.; Holland, R. E.; Stein, G. E. and Hauptman, J.G. (1992): Pharmacokinetic evaluation of ceftiofur in serum, tissue chamber fluid and bronchial secretions from healthy beefbred calves. Can. J. Vet. Res., 56(4): 269-74.

Ismail, M. M. (2005a): Disposition kinetics, bioavailability and renal clearance of cefepime in calves. Vet. Res. Comm., 29: 69-79.

Ismail, M. M. (2005b): Pharmacokinetics of cefepime administered by i.v. and i.m. routes to ewes. J. Vet. Pharmacol. Therap., 28: 499-504.

Jaglan, P. S.; Roof, R. D.; Yein, F. S.; Arnold, T. S.; Brown, S. A. and Gilbertson, T. J. (1994): Concentration of ceftiofur metabolites in the plasma and lungs of horses following intramuscular treatment. J. Vet. Pharmacol. Ther., 17 (1): 24-30.

Jaglan, P. S.; Yein, F. S.; Hornish, R. E.; Cox, B. L.; Arnold, T. S.; Roof, R. D. and Gilbertson, T. J. (1992): Depletion of intramuscularly injected ceftiofur from the milk of dairy cattle. J. Dairy Sci., 75: 1870-1876.

Kalman, D.; Barriere, S. L. and Jhonson, B. L. (1992): Pharmacokinetics, disposition and bactericidal activities of cefepime, ceftazidime and cefoperazone in serum and blister fluid. Antimicrob. Agents Chemother., 36: 453-457. Mahrt, C. R. (1992): Safety of ceftiofur sodium administered intramuscularly in horses. Am. J.Vet. Res., 53 (11): 2201-5.

Meyer, J. C.; Brown, M. P.; Gronwall, R. R. and Merritt, K. (1992): Pharmacokinetics of ceftiofur sodium in neonatal foals after intramuscular injection. Equine Vet. J. 24: 485-486.

Osbaldiston, G. W. (1971): Kidney function: In Clinical Biochemistry of Domestic Animals, $2^{\text {nd }}$ edn. Eds Kanko, J.J. and Cornelius, C.E. pp. 24-27, Academic Press, New York, USA.

Plumb, D. (1995): Drug monographs: Ceftiofur. In the Veterinary Drug Handbook, $2^{\text {nd }}$ ed. ed. Plumb, D. pp. 107-112. Iowa State Press, Ames, IA
Salmon, S. A.; Watts, J. L.; Case, C. A.; Hoffman, L. J.; Wegener, H. C. and Yancey, R. J. (1995): Comparison of MICs of ceftiofur and other antimicrobial agents against bacterial pathogens of swine from the United States, Canada, and Denmark. J. Clin. Microbiol., 33 (9): 2435-44. Salmon, S. A., Watts, J. L. and Yancey, R. J. (1996): In vitro activity of ceftiofur and its primary metabolite, desfuroylceftiofur, against organisms of veterinary importance. J. Vet. Diagn. Invest., 8 (3): 332-6.

Sams, R. A. (1994): Florfenicol: Chemistry and metabolism of a novel broad-spectrum antibiotic. International Symposium on Bovine Respiratory Disease. New Therapeutic Advances, Bologna, Italy, pp. 13-17.

Schirmeister, J.; Willmann, H. and Kidfer, H. (1981): Endogenous creatinine in serum and urine. Dtsch. Med. Wschr., 89: 1018.

Siest, G.; Henny, J.; Schielc, F. and Young, D. S. (1985): Colorimetric determination of creatinine. Interpretation of clinical laboratory tests. $3^{\text {rd }}$ ed., London.

Snedecor, G. W. and Cochran, W. G. (1976): Statistical methods. $6^{\text {th }}$ ed. Ames, Iowa, USA, pp. 502-503.

Soback, S.; Bright, S. and Paape, M. (1991): Disposition kinetics of ceftiofur in lactating cows. Acta Veterinaria Scandinavica, Suppl., 87: 93-95.

Soback, S.; Ziv, G.; Winkler, M. and Saran, A. (1989): Pharmacokinetics of ceftiofur administration intravenously and intramuscularly to lactating cows. Israel J. Vet. Med., 45 (2): 118-123.

Sweeney, C. R. and Smith, J. A. (1990): Diseases of the respiratory system. In Large Animal Internal Medicine. Ed. Smith, B.P., pp. 489-619.

Vermeersch, H.; Vandenbossche, G., Remon, J.P.; Samyn, W.; Vandendriessche, K.; Sustronck, B.; Muylle, E. and Deprez, P. (1996): Pharmacokinetics of nebulized sodium ceftiofur in calves. J. Vet. Pharmacol. Therap., 19: 152-154.

Watts, J. L.; Yancey, R. J.; Salmon, S. A. and Case, C.A. (1994): A 4-year survey of antimicrobial susceptibility trends for isolates from cattle with bovine respiratory diseases in North America. J. Clin. Microbiol., 32: 725-31.

Wenz, J. R.; Garry, F. B.; Lombard, J. E.; Elia, R.; Prentice, D. and Dinsmore, R. P. (2005): Short communication: Efficacy of parenteral ceftiofur for treatment of systemically mild clinical mastitis in dairy cattle. J. Dairy Sci., 88 (10): 3496-9.

Whittem, T.; Freeman, D. A.; Hanlon, D. and Parton, K. (1995): The effect on the pharmacokinetics of intravenous ceftiofur sodium in dairy cattle of simultaneous intravenous acetyl salicylic acid (aspirin) or probenecid. J. Vet. Pharmacol. Therap., 18: 61-67.

Yancey, R. J.; Kinney, M. L.; Roberts, B. J.; Goodenough, K. R.; Hamel, J. C. and Ford, C. W. (1987): Ceftiofur sodium, a broad-spectrum cephalosporin: evaluation in vitro and in vivo in mice. Am. J. Vet. Res., 48 (7): 1050-3. 


\section{دراسة مقارنه للمسار الحركي للسيفتيوفور في عجول الأبقار والجاموس}

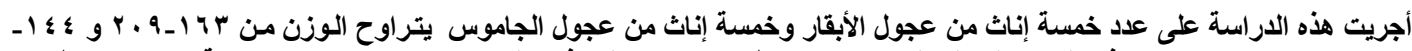

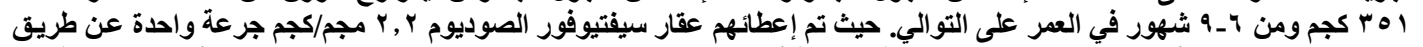

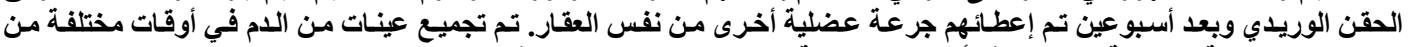

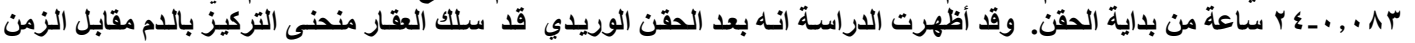

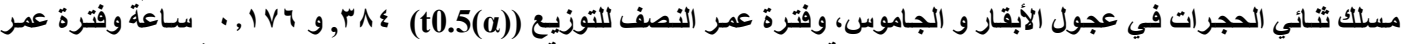

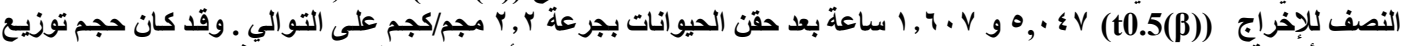

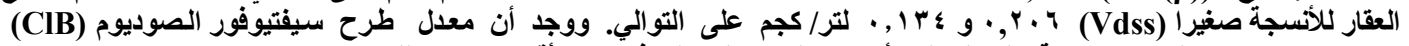

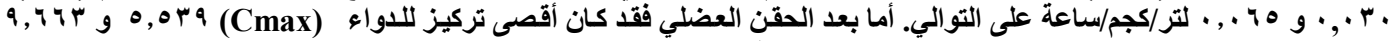

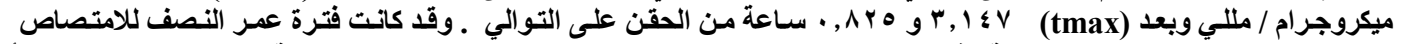

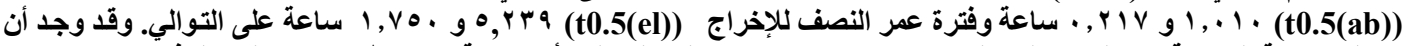

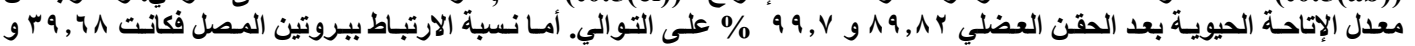

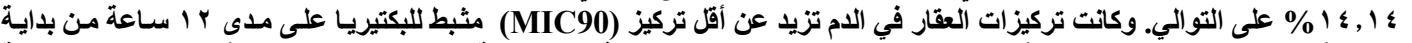

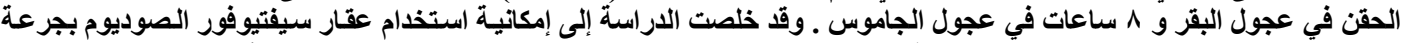

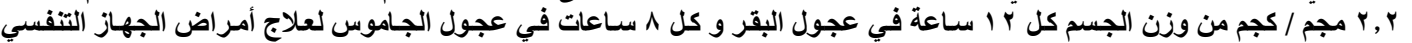

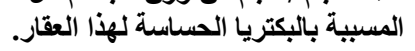

